\title{
Learning Orientation, Market Orientation and Organizational Performance: The Mediating Effect of Absorptive Capacity
}

\author{
Radwan Kharabsheh \\ Applied Science University, Kingdom of Bahrain \\ E-mail: radwan.kharabsheh@asu.edu.bh
}

Waed Ensour

Hashemite University, Jordan

Pavel Bogolybov

Lancaster University, UK

Received: November 14, 2016 Accepted: March 13, 2017

doi:10.5296/ber.v7i1.10294 URL: https://doi.org/10.5296/ber.v7i1.10294

\begin{abstract}
Purpose: this paper aims to examine the mediating effect of absorptive capacity on the the relation between two construct: learning orientation (LO) and market orientation (MO) and organizational performance (OP).

Design/methodology/approach: data were gathered through field survey of 190 senior managers in manufacturing organizations in Jordan. The analysis was conducted using two-stage least squares estimators for latent variable models.

Findings: Results indicate that learning orientation, market orientation and absorptive capacity all have a positive and significant effect on organizational performance. Moreover, results suggest that absorptive capacity partially mediates the relationship between learning orientation and organizational performance. This study concludes that while knowledge acquisition and values of external knowledge are important, related prior knowledge, basic skills and research and development (R\&D) (absorptive capacity) are important as well.
\end{abstract}

Practical implications: For managers in manufacturing organizations, the study proposes 
that organizations should focus on attaining high levels of Learning orientation and market orientation while also giving attention to building internal knowledge and basic skills including R\&D.

Originality/value: This paper is the first to examine the mediating effect of absorptive capacity on the relationship between learning orientation, market orientation and organizational performance.

Keywords: Learning orientation, Market orientation, Absorptive capacity, Organizational performance

\section{Introduction}

While an abundance of literature exists confirming the positive relationship between learning orientation (LO) and organisational performance and market orientation (MO) and organisational performance (OP), there remains a lack of clarity regarding the relative contributions of a market and learning orientation to organisational performance. For example, Baker and Sinkula (1999a) state that in the absence of one or the other, it would be better for an organization to have a strong MO. Conversely, Baker and Sinkula (1999b) argue that a MO does not have a direct effect on organisational performance. Farrell (2000) state that LO positively affects organisational performance. Whereas Farrell and Oczkowski (2002) found overall support to the claim that MO has a stronger relationship with organisational performance than does LO. In a recent study, Vijande et al. (2005) indicate a positive relationship between $\mathrm{MO}$ and organisational performance, but no effect for LO and organisational performance. Long (2013) also found a positive impact of market orientation on organizational performance but no effect of LO.

Studies also examined the effect of absorptive capacity on competitive advantage and organisational performance. Recently, absorptive capacity has been one of the most studied aspects of knowledge management (Jansen et al., 2005; Tu et al., 2006; Lane et al., 2006; Todorova and Durisin, 2007; Fosfuri and Tribó, 2008; Lichtenthaler, 2009; Tortoriello, 2015).

Absorptive capacity refers to the ability to acquire, understand, employ, and eventually take advantage of knowledge available outside the organization (Tortoriello, 2015). Absorptive capacity has been recognized as an important driver of organizations innovative performance, sustainable competitive advantage and drivers of organisational performance (Zahra and George, 2002; Jansen, Van Den Bosch and Volerda, 2003; Lenox and King, 2004; Tu et al., 2006; Fosfuri and Tribó, 2008; Tortoriello, 2015).

Few studies paid attention to the mediating effect absorptive capacity on the relationship between LO, MO and organisational performance. Di Zhang (2009) examined the mediating effect of absorptive capacity on the link between organisational strategic orientations (such as learning orientation and market orientation) and organisational performance outcome indicators (such as innovation, customer satisfaction and loyalty, and financial performance). He found that absorptive capacity mediated the relationship between strategic orientation and organisational performance. Gutiérrez et al., (2010) studied the relation between absorptive capacity and organizational learning in a - total quality management (TQM) context. They 
found that a positive and significant relationship exists between absorptive capacity and organizational learning orientation. Lord (2012), in a study of institutional investment management, found that greater absorptive capacity contributes to greater portfolio diversification and higher risk-adjusted returns over a five-year period and that a committee's absorptive capacity partially mediates the effect of its members' expertise in diverse asset classes on portfolio diversification.

However, these studies are undermined by some important limitations. For example, Di Zhang's (2009) study narrowly examined the mediating effect of absorptive capacity on the relationship between $\mathrm{LO}, \mathrm{MO}$ and organisational performance without examining the direct effects of LO and MO on organisational performance. Gutiérrez et al., (2010) examined organisational learning orientation and did not use the well-established LO construct developed by Baker and Sinkula (1999b). The study was also conducted in a TQM context with a narrow focus on TQM teams. Lord's (2012) study examined the mediating effect of realised and potential absorptive capacity in an investment management context. This paper aims to examine the relative contribution of LO, MO and absorptive capacity on organizational performance in addition to assessing the mediating effect of absorptive capacity on the relationship between LO, MO and organisational performance.

\section{Literature review}

\subsection{Learning Orientation}

Learning orientation refers to the extent to which organisations obtain and share information concerning changes in the market, customers' expectations and needs, competitors' actions, and new technologies' development, in order create new products or services that are superior to those of competitors (Calantone et al., 2002).

Bennett (1998) state that commitment to learning necessitates top management support, training initiatives, and the payment of whom who translate their learning into superior performance. Basically, workers must be encouraged to challenge the status quo, to develop new ideas, innovate, and continuously evaluate their activities with a view to improving performance. The relation between LO and organizational performance was the interest of many scholars. In this context, several studies declare a positive effect of LO on organisational performance (Baker and Sinkula, 1999a; Farrell and Oczkowski, 2002; Calantone, et al., 2002; Celuch, et al., 2002; Farrell, et al., 2008; Martinette and Obenchain-Leeson, 2012).

\subsection{Market Orientation}

MO refers to an organization-wide generation of market intelligence pertaining to current and future customer needs, spreading of intelligence across departments and organization-wide responsiveness to it (Kohli and Jaworski, 1990). In other words, MO involves the use of superior organizational skills in understanding and satisfying customers. It facilitates an organization's ability to anticipate, react to, and capitalise on environmental changes, thus, leading to superior performance (Mahmoud and Yusif 2012). 
Narver and Slater (1990) state that MO has three components. The first component is customer orientation, which reflects the needed activities for acquiring and circulating customers' information. The second component refers to competitor orientation, which requires an effort to gather and disseminate information about competitors of the market-oriented organization. The third component, refers to interfunctional coordination, encompasses the integration of all organization's functional units to create superior value for customers (Narver and Slater, 1990).

Celuch et al. (2002) examine the effect of MO and LO on organizational capabilities. Calantone et al. (2002) study the effects of a LO on organization innovation capability and performance, results indicate a positive relationship between LO and organization performance (market share, new product success and overall performance). Calantone et al.(2002) state that LO facilitates the generation of resources and skills essential for organization performance. Vijandeet et. al., (2005) found that MO has a positive effect on organizational performance, whereas LO has a negative direct relationship with performance. Farrell and Oczkowski (2002) found that MO has a stronger relationship with organizational performance than does LO. Long (2013) found a positive impact of MO on organization performance but no effect for LO.

\subsection{Absorptive Capacity}

Absorptive capacity has been heavily examined by researchers in their analysis of diverse, significant and complex organizational phenomena (Zahra and George, 2002). Moreover, absorptive capacity has been studied across the fields of strategic management, technology management, international business and organizational economics (Lane and Lubatkin, 1998; Kedia and Bhagat, 1988; Glass and Saggi, 1998). Researchers believe that organizations endowed with high level of absorptive capacity could help attain their competitive advantage and outperform their competitors (Yan, 2014). Patel et al., (2015) state that absorptive capacity plays a role in both increasing and managing variations in innovation outcomes. Moreover, Tsai (2001) state that an organization's absorptive capacity is closely linked to its innovation performance, as well as financial performance (Kostopoulos, Papalexandris, Papachroni, and Loannou, 2011). Roper and Xia (2014) found that absorptive capacity plays an important role in determining organization's growth.

Cohen and Levinthal (2007) state that the ability of an organization to identify the value of new, external information, assimilate it, and apply it to commercial ends is significant to its innovative capabilities. More importantly, they show that the ability to evaluate and utilize outside knowledge is mainly a function of the level of prior related knowledge which encompass basic skills or a shared language, but may also include knowledge of the most up to date scientific and technological developments in a particular field. Therefore, they indicate that, prior related knowledge confers an ability to recognize the value of new information, assimilate it, and apply it to commercial ends. These abilities collectively constitute what is called an organization's "absorptive capacity."

Zahra and George (2002) conceptualise absorptive capacity as a set of organizational processes through which organizations acquire, assimilate, transform and exploit knowledge, 
in order to enhance the organization's ability to gain and sustain a competitive advantage. Zahra and George (2002) suggest that absorptive capacity has two dimensions: potential absorptive capacity, which relates to knowledge acquisition and assimilation capability. The second dimension is realised capacity that focuses on the transformation and exploration of knowledge. In this context, Patel et al., (2015) state that potential absorptive capacity enhances the effects of entrepreneurial orientation on variability in innovation outcomes, while realized absorptive capacity helps transform and exploit variability in innovation outcomes to enhance organizations performance.

Cohen and Levinthal (1990) argue that organizational absorptive capacity depends on the absorptive capacities of its individual members. Therefore, absorptive capacity builds on prior investment in the development of its constituent, individual absorptive capacities. And, like individuals' absorptive capacities, organizational absorptive capacity will tend to develop cumulatively. However, they argue that an organization's absorptive capacity is not simply the sum of the absorptive capacities of its employees, rather it should include organizational aspects. Therefore, absorptive capacity refers not only to the acquisition or assimilation of information by an organization, but also to the organization's ability to use and develop it.

Organizational absorptive capacity is generated in a variety of ways. Cohen and Levinthal (1990) contend that absorptive capacity may be created as a byproduct of an organization's research and development (R\&D) investment. Other researchers suggest that absorptive capacity may also could be developed as a result of an organization's manufacturing operations. For example, Abernathy (1978) and Rosenberg (1982) note that through direct involvement in manufacturing, an organization is better able to recognize and exploit new information relevant to a particular product market. Production experience provides the organization with the background necessary both to recognize the value of and implement methods to reorganize or automate particular manufacturing processes. Organizations also invest in absorptive capacity directly when they send personnel for advanced technical training (Cohen and Levinthal, 2000). Therefore, it is expected that absorptive capacity will have a positive effect on organizational performance in the form of new product development, new product success and profitability.

\subsection{The Mediating Effect of Absorptive Capacity}

Few studies examined the mediating effect of absorptive capacity on the relationship between LO, MO and organizational performance. Di Zhang (2009) found that absorptive capacity mediated the relationship between strategic orientation and organizational performance. Gutiérrez et al. (2010) found a positive and significant relationship between absorptive capacity and organizational learning orientation. Lord (2012) argue that a greater absorptive capacity contributes to a greater portfolio diversification and higher risk-adjusted returns over a five-year period and that a committee's absorptive capacity partially mediates the effect of its members' expertise in diverse asset classes on portfolio diversification.

While learning orientation focuses on commitment and agreement of organizational members and their ability to unlearn old knowledge, and market orientation focuses on translating collected knowledge into actions, they are different from absorptive capacity. Absorptive 
capacity works both at the individual and organizational levels to build on old and existing knowledge, and promotes internal knowledge development which makes external knowledge more generally usable regardless of its goal. Indeed, Tu et al. (2006) indicate that while the definitions of absorptive capacity show a clear orientation to external knowledge and information implicit in the definition is the notion that organizations are aware of internal information and have access to it. More importantly, absorptive capacity has an explicit focus on transformation and exploitation of knowledge, that is, transformation through combining existing and new, acquired and assimilated knowledge, and exploitation, which is based on routines that facilitate improvement, expansion, and influence on existing capacities or generation of new ones, thanks to the knowledge acquired and transformed (Zahara and George, 2002; Gutiérrez et al., 2010;). Furthermore, Roper and Xia (2014) indicate that strong internal capabilities (both learning and marketing capabilities) may enable an organization to more effectively target, absorb and deploy the external knowledge necessary to drive organization's innovation.

In more details, Lichtenthaler (2009) argue that exploratory learning involves knowledge acquisition (Lane et al., 2006) and corresponds to the idea of potential absorptive capacity (Zahra and George, 2002). Whereas exploitative learning relates to knowledge assimilation and utilization (Lane et al., 2006; Todorova and Durisin, 2007; Lichtenthaler, 2009), reflecting the concept of realized absorptive capacity (Zahra and George, 2002). Schilling (2002) argue that if organizations want to be learning oriented, investing in learning creates absorptive capacity and thus improves the rate at which the organization can learn. Further, in terms of prior knowledge and familiarity with new knowledge, Lane et al. (2006) affirm that absorptive capacity results in assimilation of sought-after knowledge.

\subsection{Research Hypothesis}

Based on the earlier literature review, the following hypothesis were generated:

H1: Higher levels of learning orientation results in higher levels of organizational performance

H2: Higher levels of market orientation result in higher levels of organizational performance

H3: higher levels of absorptive capacity result in higher levels of organizational performance

H4: Absorptive capacity mediates the relationship between learning orientation and organizational performance

H5: Absorptive capacity mediates the relationship between market orientation and organizational performance

\section{Methodology}

\subsection{Data Collection}

The study utilized a self-administered questionnaire survey of all Jordanian companies listed on the Jordanian stock market. Senior managers of the companies, heads of units and departments were informed of the nature of the study and its objectives and were assured of 
the anonymity of their personal and organizational data. In total 190 usable questionnaires were returned.

\subsection{Measures}

LO was measured using the Baker and Sinkula (1999) measure, which consists of: commitment to learning ( 3 items), shared vision ( 3 items), open-mindedness ( 3 items), and Intra-organizational knowledge sharing ( 3 items). MO was measured by MKTOR developed by Narver and Slater (1990) and Slater and Narver (1994) which consists of three sub-constructs: customer orientation (6 items), competitor orientation (4 items), and interfunctional coordination (4 items). Absorptive capacity was measured by a 6 item measure developed by Szulanski (1996).

The study measured organizational performance through five dimensions of business performance relative to all other competitors in the organization's principal served market segment over the past year: customer retention; new product success; sales growth; return on investment; and overall performance. The study examines these measures individually and as five indicators in a five item scale named business performance.

\subsection{Analysis Procedures}

In order to test the model, we have conducted a partial least square analysis (PLS).

PLS is a "second generation regression model that combines a factor analysis with linear regressions, making only minimal distribution assumptions" (Gefen et al., 2000, p.71). PLS allows for testing second order constructs and is suitable for complex models with numerous exogenous and endogenous variables.

\subsubsection{Measurement Model}

First, we measured the reliability and validity of the model. We checked the internal reliability of our model by measuring Cronbach's alpha. The Cronbach's alphas for our constructs range between 0.72 and 0.90 , thus showing satisfactory levels of reliability. The Cronbach's alphas for all the constructs are presented in Table 1.

Table 1. Reliability results

\begin{tabular}{|l|l|}
\hline Construct & Cronbach's Alpha \\
\hline Learning orientation & 0.90 \\
\hline Market Orientation & 0.89 \\
\hline Absorptive capacity & 0.82 \\
\hline Organizational performance & 0.72 \\
\hline
\end{tabular}

Subsequently, a confirmatory factor analysis was conducted to assess convergent and discriminant validity. First, the factor loadings were examined. A number of items were excluded because of low factor loadings, shown in Table 2. 
Table 2. Items excluded due to low factor loadings or to increase discriminant validity

\begin{tabular}{|l|l|}
\hline Item deleted & Factor loading \\
\hline AC1 & 0.703 \\
\hline MoCus6 & 0.565 \\
\hline MoCmp7 & 0.676 \\
\hline MoFun11 & 0.652 \\
\hline MoFun12 & 0.552 \\
\hline P3 & 0.703 \\
\hline P4 & 0.620 \\
\hline
\end{tabular}

All, but two factors loadings were greater than 0.6 which shows acceptable convergent validity (Hair et al., 2014). Additionally, to address convergent validity, average variance extracted was measured. The results are presented in Table 3.

Table 3. Average Variance Extracted Results

\begin{tabular}{|l|l|}
\hline Construct & AVE \\
\hline Learning orientation & 0.48 \\
\hline Market Orientation & 0.41 \\
\hline Absorptive capacity & 0.58 \\
\hline Organizational performance & 0.66 \\
\hline
\end{tabular}

Table 3 shows the constructs' AVEs. Fornell and Larcker (1981) recommended an AVE above 0.5 to indicate convergent validity. The AVEs in table 3 are either close enough to 0.5 or higher than the 0.5 recommended value indicating convergent validity.

\subsubsection{Structural Model}

To test the structural model and the hypotheses, path coefficient analysis and bootstrapping procedure with 5000 re-samplings were performed. The results are provided in Figure 1.

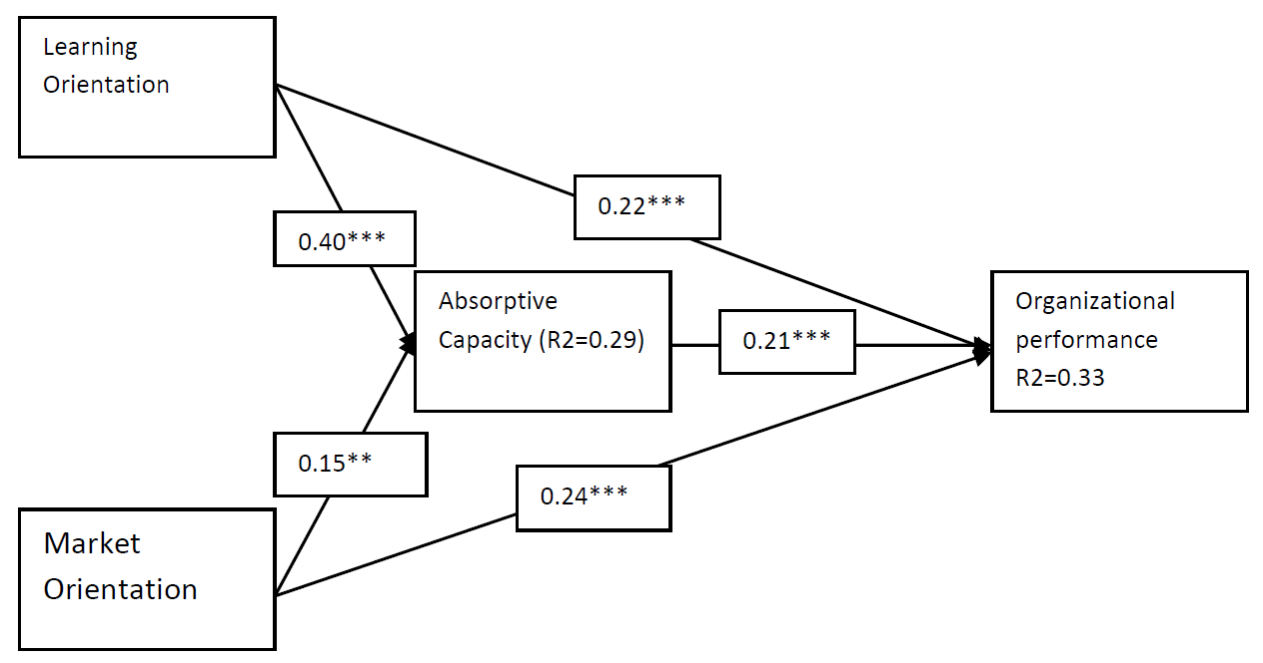

Figure 1. PLS analysis results 


\section{MInstitute ${ }_{\text {Intm }}^{\text {Macrothink }}$}

Business and Economic Research

ISSN 2162-4860

2017, Vol. 7, No. 1

First, as part of the analysis, the coefficient of determination was assessed (R2). R squared for absorptive capacity was 0.29 and for organizational Performance, 0.33. This means that the variance in the dependent variables can be explained by the independent variables by $29 \%$ and $33 \%$ respectively.

Next step was to assess the path coefficients and their significance levels. The findings supported our proposed model. A moderate positive and significant relationship was evident in the link between LO and absorptive capacity, while weaker but significant relationships existed between absorptive capacity and OP, LO and OP, MO and OP and MO and absorptive capacity. This shows that learning orientation, market orientation and absorptive capacity all had a positive effect on organizational performance with the highest being that of absorptive capacity. It also shows that learning and market orientations had almost comparable effect on organizational performance, as well as that absorptive capacity had a mediation effect on the relationship between LO and OP with a total effect of $(0.22+0.40 * 0.27=0.33)$ which was higher than the direct 0.22 . It also had a mediating effect on the relationship between MO and organizational performance with a total effect of $\left(0.24+0.15^{*} 0.21=0.27\right)$. A summary of the hypotheses and the results is presented in Table 4 indicating a full mediation effect in the two cases.

Table 4. Summary of the hypotheses and the results

\begin{tabular}{|l|l|}
\hline Hypothesis & Result \\
\hline $\begin{array}{l}\text { H1. higher levels of learning orientation results in higher } \\
\text { levels of organizational performance }\end{array}$ & Supported \\
\hline $\begin{array}{l}\text { H2. higher levels of market orientation results in higher } \\
\text { levels of organizational performance }\end{array}$ & Supported \\
\hline $\begin{array}{l}\text { H3. higher levels of absorptive capacity results in higher } \\
\text { levels of organizational performance }\end{array}$ & Supported \\
\hline $\begin{array}{l}\text { H5. absorptive capacity mediates the relationship between } \\
\text { learning orientation and organizational performance }\end{array}$ & Supported \\
\hline $\begin{array}{l}\text { H4. absorptive capacity mediates the relationship between } \\
\text { market orientation and organizational performance }\end{array}$ & Supported \\
\hline
\end{tabular}

\section{Discussions and Conclusions}

This study aimed at examining the relative contribution of LO, MO and absorptive capacity on organizational performance. In addition this study intended to assess the mediating effect of absorptive capacity on the relationship between LO, MO and organisational performance. The study found a moderate positive and significant relationship between LO and absorptive capacity and weaker relationships between LO and OP, MO and organizational performance, and MO and absorptive capacity. More importantly, the study found a mediating effect of absorptive capacity on the relationship between learning orientation and organizational performance and the relationship between market orientation and organizational performance.

These findings have practical usefulness. Organizations which are able to recognize and acquire relevant external information, are then able to apply or exploit their expanded 
knowledge. In this era of increased competition, market conditions are always changing, and new competitive strategies are constantly being developed and used. Investment fiduciaries must have the ability to obtain relevant information in a dynamic environment and then to capitalize on it. Organizations need to focus on endowing their employees with knowledge values, a shared vision and commitment to learning (high learning orientation). At the same time, organizations need to focus on their competitors and customers who represent their business in the present and the future (high market orientation). Also, managers should make substantial investment in corporate dynamic capabilities, such as absorptive capacity, which emphasizes on the assimilation and exploitation of knowledge and market intelligence already learned. The study suggests that cultivating an organizational absorptive capacity would magnify the benefits of learning and generating market intelligence. Organizations need to be able to transform and exploit their acquired knowledge into products, services and outcomes in order to satisfy their different stakeholders: including employees, investors and customers (high absorptive capacity).

\section{Limitation and Future Research}

One limitation for this study is the small sample size. PLS requires bigger samples to work better. Future studies can increase the sample size so that better discriminant validity and estimations are reached. Another limitation of the study is the need to include control variables for organizational performance. Researchers argued that numerous variables can affect organizational performance and should be included in the analysis to obtain better results. For example, Narver and Slater (1990) and Farrel and Ockowzki (1998) argued that several variables may be used as controls in analyzing the effect of a market and learning orientation on performance such as: relative size, relative cost, ease of entry, supplier power, buyer power, market growth, competitive intensity, market turbulence, and technological turbulence.

\section{References}

Abernathy, W. J. (1978). The Productivity Dilemma. Baltimore. Johns Hopkins University Press.

Baker, W. E., \& Sinkula J. M. (1999b). Learning Orientation, Market Orientation and Innovation: Integrating and Extending Models of Organizational Performance, Journal of Market Focussed Management, 4(4), 295-308. https://doi.org/10.1023/A:1009830402395

Baker, W. E., \& Sinkula, J. M. (1999a). The Synergistic Effect of Market Orientation and Learning Orientation on Organizational Performance, Journal of the Academy of Marketing Science, 27(4), 411-427. https://doi.org/10.1177/0092070399274002

Bennett, R. (1998). Charities, Organizational Learning and Market Orientation: A Suggested Measure of the Propensity to Behave as a Learning Organisation, Journal of Marketing Practice: Applied Marketing Science, 4(1), 5-25.

https://doi.org/10.1108/EUM0000000004482

Calantone, R. J., Cavusgil, S. T., \& Zhao, Y. (2002). Learning Orientation, Firm Innovation 


\section{Macrothink}

Business and Economic Research ISSN 2162-4860 2017, Vol. 7, No. 1

Capability, and Firm Performance, Industrial Marketing Management, 31(6), 515-524. https://doi.org/10.1016/S0019-8501(01)00203-6

Celuch, K. G., Kasouf, C. J., \& Peruvemba, V. (2002). The Effects of Perceived Market and Learning Orientation on Assessed Organizational Capabilities, Industrial Marketing Management, 31(6), 545-554. https://doi.org/10.1016/S0019-8501(01)00203-6

Cohen, W., \& Levinthal, D. (1990). Absorptive Capacity: A New Perspective on Learning and Innovation, Administrative Science Quarterly, 35(1), 128-152.

https://doi.org/10.2307/2393553

Cohen, W., \& Levinthal, D. (2000). Absorptive Capacity: A New Perspective on Learning and Innovation, in Strategic learning in a knowledge economy, in (Eds) Robert Cross and Sam Israelit, Butterworth-Heinemann, 39-68.

https://doi.org/10.1016/B978-0-7506-7223-8.50005-8

Day, G. S. (1994). The Capabilities of Market Driven Organizations, Journal of Marketing, 58(4), 37-52. https://doi.org/10.2307/1251915

Di Zhang, D. (2009). Absorptive Capability and its Mediating Effect on the Learning and Market Orientations' Influences on Performance, International Journal of Technology Marketing, 4(2/3), 275-288. https://doi.org/10.1504/IJTMKT.2009.026874

Dickson, P. R. (1992). Toward a General Theory of Competitive Rationality, Journal of Marketing, 56(1), 69-83. https://doi.org/10.2307/1252133

Farrell, M. A. (2000). Developing a Market-Oriented -Learning Organisation, Australian Journal of Management, 25(2), 201-22. https://doi.org/10.1177/031289620002500205

Farrell, M. A., \& Oczkowski, E. (2002). Are Market Orientation and Learning Orientation Necessary For Superior Organizational Performance?, Journal of Market-Focused Management, 5(3), 197-217. https://doi.org/10.1023/A:1022990622706

Farrell, M., Oczkowski, E., \& Kharabsheh, R. (2008). Market Orientation, Learning Orientation and Organizational Performance in International Joint Ventures, Asia Pacific Journal of Marketing and Logistics, 20(3), 289-308.

https://doi.org/10.1108/13555850810890066

Fornell, C., \& Larcker, D. F. (1981). Evaluating Path Analysis Models with Unobservable Variables and Measurement Error, Journal of Marketing Research, 18, 39-50.

https://doi.org/10.2307/3151312

Fosfuri, A. Y., \& Tribó, J. A., (2008). Exploring the Antecedents of Potential Absorptive Capacity and its Impact on Innovation Performance. Omega, 36(2), 173-187.

https://doi.org/10.1016/j.omega.2006.06.012

Gefen, D., Straub, D., \& Boudreau, M., (2000). Structural Equation Modeling and Regression: Guidelines for Research Practice, Communications of the Association For Information System, 4(7), 1-78. 
Glass, A. J., \& Saggi, K. (1998). International Technology Transfer and the Technology Gap, Journal of Development Economics, 55(2), 369-398.

https://doi.org/10.1016/S0304-3878(98)00041-8

Gutiérrez, L., Bustinza, O., \& Barrales, V. (2010). Six Sigma, Absorptive Capacity and Organizational Learning Orientation, International Journal of Production Research, 50(3), 661-675. https://doi.org/10.1080/00207543.2010.543175

Hair Jr, J. F., Hult, G. T. M., Ringle, C., \& Sarstetd, M. (2014). A Primer on Partial Least Squares Structural Equation Modeling (PLS-SEM), SAGE Publications.

Hau, Y. S., Kim, B., Lee, H., \& Kim, Y.-G. (2013). The Effects of Individual Motivations and Social Capital on Employees' Tacit and Explicit Knowledge Sharing Intentions, International Journal of Information Management, 33(2), 356-366.

https://doi.org/10.1016/j.ijinfomgt.2012.10.009

Jansen, J., Van Den Bosch, F., \& Volerda, H. (2003). Absorptive Capacity, Adapatation, and Performance: An Intra-Organsiational Perspective, OKLC Conference, Barcelona.

Kedia, B. L., \& Baharat, R. S. (1988). Cultural Constraints on Transfer of Technology Across Nations: Implications for Research in International and Comparative Management. Academey of Management Review, 13(4), 559-571.

Kohli, A., \& Jaworski, B. (1990). Market Orientation: the Construct, Research Propositions, and Managerial Implications, Journal of Marketing, 54(2), 1-18.

https://doi.org/10.2307/1251866

Kostopoulos, K., Papalexandris, A., Papachroni, M., \& Ioannou, G. (2011). Absorptive Capacity, Innovation, and Financial Performance. Journal of Business Research, 64(12), 1335-1343. https://doi.org/10.1016/j.jbusres.2010.12.005

Lane, P. J., \& Lubatkin, M. (1998). Relative Absorptive Capacity and Interorganizational Learning, Strategic Management Journal, 19(5), 461-477.

https://doi.org/10.1002/(SICI)1097-0266(199805)19:5<461::AID-SMJ953>3.0.CO;2-L

Lane, P. J., Koka, B., \& Pathak, S., (2006). The Reification of Absorptive Capacity: A Critical Review and Rejuvenation Of The Construct. Academy of Management Review, 31(4), 833-863. https://doi.org/10.5465/AMR.2006.22527456

Lenox, M., \& King, A. (2004). Prospects for Developing Absorptive Capacity through Internal Information Provision. Strategic Management Journal, 25(4), 331-345. https://doi.org/10.1002/smj.379

Lichtenthaler, U. (2009). Absorptive Capacity, Environmental Turbulence, and the Complementarity of Organizational Learning Processes, .Academy of Management Journal, 52(4), 822-846. https://doi.org/10.5465/AMJ.2009.43670902

Long, H. (2013). The Relationship among Learning Orientation, Market Orientation, Entrepreneurial Orientation, and Firm Performance of Vietnam Marketing Communications 
Firms. Philippine Management Review, 20, 37-46.

Lord, M. (2012). Absorptive Capacity, Learning Orientation and Institutional Investment Management, PhD Desertation, Weatherhead School of Management, Case Western Reserve University.

Mahmoud, M., \& Yusif, B. (2012). Market Orientation, Learning Orientation, and the Performance of Nonprofit Organisations (NPOs), International Journal of Productivity and Performance Management, 61(6), 624-652. https://doi.org/10.1108/17410401211249193

Martinette, A., \& Obenchain-Leeson, A. (2012). The Relationship Between Learning Orientation and Business Performance and The Moderating Effect of Competitive Advantage: A Service Organization Perspective. Journal of Srvice Science, 5(1), 779-792. https://doi.org/10.19030/jss.v5i1.6940

Narver, J., \& Slater, S. (1990). The Effect of a Market Orientation on Business Profitability, Journal of Marketing, 54(4), 20-35. https://doi.org/10.2307/1251757

Oczkowski, E. (2002). Discriminating Between Measurement Scales Using Nonnested Tests and 2SLS: Monte Carlo Evidence, Structural Equation Modelling, 9(1), 103-25. https://doi.org/10.1207/S15328007SEM0901_6

Pokharel, M., \& Choi, S. (2015). Exploring the Relationships between the Learning Organization and Organizational Performance, Management Research Review, 38(2), 126-148. https://doi.org/10.1108/MRR-02-2013-0033

Roper, S., \& Xia, H. (2014). Unpacking Open Innovation: Absorptive Capacity, Exploratory and Exploitative Openness and the growth Of Entrepreneurial Biopharmaceutical Firms, Enterprise Research Centre, 19, 1-47.

Rosenberg, N. (1982). Inside the Black Box: Technology and Economics. New York: Cambridge University Press.

Schilling, M. A. (2002). Technology Success and Failure in Winner-Take-All Markets: the Impact of Learning Orientation, Timing, and Network Externalities. Academy of Management Journal, 45(2), 387-398. https://doi.org/10.2307/3069353

Slater, S., \& Narver, J. (1995). Market Orientation and the Learning Organization, Journal of Marketing, 59(3), 63-74. https://doi.org/10.2307/1252120

Todorova, G., \& Durisin, B. (2007). Absorptive Capacity: Valuing a Reconceptualization. Academy of Management Review, 32(3), 774-786.

https://doi.org/10.5465/AMR.2007.25275513

Tortoriello, M. (2015). The Social Underpinnings of Absorptive Capacity: The Moderating Effects of Structural Holes on Innovation Generation Based on External Knowledge, Strategic Management Journal, 36(4), 586-597. https://doi.org/10.1002/smj.2228

Tsai, W. (2001). Knowledge Transfer in Intraorganizational Networks: Effects of network position and absorptive capacity on business unit innovation and performance. Academy of 
Management Journal, 44(5), 996-1004. https://doi.org/10.2307/3069443

Tu, Q., Vonderembse, M. A., Ragu-Nathan, T. S., \& Sharkey, T. W. (2006). Absorptive Capacity: Enhancing the Assimilation of Time-Based Manufacturing Practices. Journal of Operations Management, 24(5), 692-710. https://doi.org/10.1016/j.jom.2005.05.004

Vijande, M. L., Pe'rez, M. J., Gonza'lez, L. I., \& Casielles, R. V. (2005). Organizational Learning and Market Orientation: Interface and Effects on Performance, Industrial Marketing Management, 34(3), 187-202. https://doi.org/10.1016/j.indmarman.2004.08.004

Yan, Y. (2014). The Development of Absorptive Capacity In Large Firm--A Longitudinal Exploratory Study On Garmin's Automotive/Mobile Segment Over Time Span, 3rd IBA Bachelor Thesis Conference, Enschede, The Netherlands.

Zahara, S., \& George, G. ( 2002). Absorptive Capacity: A Review, Reconceptualization and Extension. Academy of Management Review, 27(2), 185-203.

\section{Copyright Disclaimer}

Copyright for this article is retained by the author(s), with first publication rights granted to the journal.

This is an open-access article distributed under the terms and conditions of the Creative Commons Attribution license (http://creativecommons.org/licenses/by/3.0/). 